DOI 10.37882/2223-2982.2021.05-2.14

\title{
ИТАЛЬЯНСКИЕ ЗАИМСТВОВАНИЯ ВО ФРАНЦУЗСКОМ ЯЗЫКЕ
}

\section{ITALIAN LOANWORDS IN FRENCH}

\section{E. Krivosheeva}

I. Likhatcheva

Summary: This article examines the history, causes, and process of the penetration of Italian loanwords into the French language, and shows the areas in which Italian loanwords are most pronounced.

Keywords: borrowing, Italianism, French, Italian, sphere, contact.

\author{
Кривошеева Елена Николаевна \\ Стариий преподаватель, РУДН (МОСКВА) \\ krivosheeva.elena.1969@mail.ru \\ Лихачева Ирина Федоровна \\ Преподаватель, РУДН (МОСКВА) \\ irina_liha@mail.ru
}

Аннотация: В данной статье рассматривается история, причины и процесс проникновения итальянских заимствований во французский язык, показаны сферы, в которых наиболее ярко выражены итальянские заимствования.

Ключевые слова: заимствование, итальянизм, французский язык, итальянский язык, сфера, контакт.

\section{Введение}

$\mathrm{P}$ азвитие языка протекает неотрывно от развития общества, так, межкультурные контакты, сопряженные с контактами межъязыковыми, способствуют взаимовлиянию языка социальной или этнической группы с языками тех групп, с которыми осуществляется межкультурная коммуникация.

В результате таковой коммуникации родной язык группы заимствует слова из другого, иностранного, что является одним из основных и успешных способов обогащения языка как системы в целом. Таким образом, заимствованием называют процесс переноса слов неисконного происхождения из одного языка в другой в результате территориальных и культурных контактов.

Французский язык содержит большое количество итальянских заимствований, что обусловлено тем значительным следом, который итальянский язык оставил в истории развития французского языка.

Итальянский язык оказал свое наибольшее влияние на французский в XVI и XVIII веках. Исторически итальянские заимствования, или итальянизмы, преимущественно связаны с военными кампаниями в Италии (с 1494 по 1558 гг.), а та, а также с растущим влиянием итальянской культуры в XVI в.

Объектом исследования является изучение заимствований из итальянского языка. Предметом исследования являются слова и выражения итальянского происхождения, используемые во французском языке.

Цель работы: исследовать итальянские лексемы во французском языке.

\section{Методы и материалы}

Как и большинство иностранных терминов, италья- низмы относятся к сферам определенной человеческой деятельности. Война с Италией и знакомство с итальянской военной сферой ввели во французский язык такие военные термины (примеры приводятся в порядке от французского заимствования к итальянскому оригиналу), как: attaquer - attaccare, barricade - barricata, bastion bastione, bataillon - battaglione, brigade - brigata, canon - canone: cantine - cantina, cartouche - cartoccio, cavalcade - cavalcata, cavalerie - cavalleria, cavalier cavalière, citadelle - cittadella, colonel - colonnello, caporal - caporale, escadron - squadrone, escorte - scorta, fantassin - fantaccino, parapet - parapetto, sentinelle sentinella, soldat - soldato. К ним также относят морские термины, такие как: boussole - bossolo, escadre - squadra, golfe - golfo, frégate - fregata.

Сходство образа жизни при королевском дворе в обоих государствах способствовало проникновению следующих слов: altesse - altessa, ambassade - ambasciata, cortège - corteggio, courtisan - conigiano, mascarade mascarata, page - paggio.

Влияние итальянского искусства во Франции, особенно в области архитектуры, музыки, живописи также наложило отпечаток на лексический состав французского языка. Среди них можно выделить термины архитектуры и орнаментации: balcon - balcone, cabinet - cabinetto, façade - facciata. belvédère - belvédère, corridor corridors, pergola; faïence - faenza, maquette - macchietta, fresquefresco, mosaïque - mosaico; музыкальные термины (особое распространение в XVIII в.): ariette - arietta, arpège - arpeggio, concerto, finale $(\mathrm{m})$, ténor, bel canto, sérénade - serenata, proprement « ciel serein ». barcarolle - barcarola, opéra - opera; термины, связанные с живопиcью: aquarelle - acquarello, pittoresque - pittoresco, pastel - pastello.

Проникновение итальянских купцов и банкиров в города на юге Франции и их интеграция в обще- 
ственную жизнь также способствовали распространению итальянизмов. Торговые отношения, влияние финансовой системы привнесли большое количество специальных терминов: banque - banca. banqueroute - banca rotta - «banc rompu» (on brisait le comptoir du banquier qui faisait faillite), bilan - bilancio, crédit - crédita, faillite - fallito.

Заимствовались и термины, обозначающие понятия повседневной жизни: brocoli, macaroni, macaron, spaghetti, ravioli, chipolata - cipollata, tombola.

Влияние итальянского языка на французский было настолько сильным, что некоторые итальянские слова вытеснили слова французского происхождения. Так, итальянские canaille, cavalerie, guirlande вытеснили бывшие в употреблении французские слова chenaille, chevalerie, garlande.

Процесс заимствования слов происходит по сей день. Недавно во французском языке появились слова pizzeria, scampi, tortellini, paparazzi, papamobile (бронированный автомобиль Папы) и просторечное междометиe tchao.

Романским языкам свойственны диминутивные образования. Так, шведский романист Б. Хассельрот отмечает большое количество диминутивных суффиксов в итальянском, а также большую активность суффикса -ito (-itto, -tico) (Hasselrot 1957: 245, 255-256, 269).
Французский язык, начиная с XVII -го века - периода его нормализации, имеет в этом отношении свои особенности. Во французском существует только один суффикс с уменьшительным значением -et /-ette, тогда как в итальянском их несколько: -etto/ -etta, -ino/-ina, -otto/-otta. Кроме того, в итальянском имеются суффиксы со значением увеличения: -accio/ -accia (poveraccio), -one/ -ona (librone), -astro/ -astra (poetastro) (Serianni 1989: 551). Следовательно, в итальянском, в отличие от французского, можно говорить о системе уменьшительно-увеличительных суффиксов. Главной же особенностью французского суффикса -et/ -ette является то, что он не всегда имеет уменьшительное значение. Так, по моим подсчётам, произведенным по обратному словарю (Juilland) из 132 слов на -ette, производных от существительных лишь 80 (60\%) имеют сему уменьшительности. Остальные 40\%, приобретая другое значение, теряют связи с производящим словом: aiguille - aiguillette. Сопоставительный анализ тестов новелл Л. Пиранделло и их переводов на французский язык показывает, что диминутивы передаются на французский язык тремя способами:

1. диминутивами : la casetta -une maisonnette;

2. непроизводными словами : una formichetta - une fourmie;

3. словосочетаниями --- простое слово+прилагательное: quella povera aminiccia - cette pauvre petite âme (Цыбова 2008: 504-505).

Согласно подсчётам (Hasselrot 1957: 279), распреде-

\begin{tabular}{|c|c|}
\hline Итальянский язык & Французский язык \\
\hline $\begin{array}{l}\text { Avere la testa quadrata } \\
\text { буквальный перевод: «Иметь квадратную голову», т.е. быть очень умным че- } \\
\text { ловеком. В то же время выражение «tеsta quadra» имеет прямо противополож- } \\
\text { ный смысл - быть чудаком, психом, безмозглым, ненормальным, чокнутым. } \\
\text { Пример: Не слушай меня! Ты обычная квадратная голова! } \\
\text { - Testa di cavolo / di legno / di rapa - уничижительное сравнение головы, а } \\
\text { именно мыслительных способностей человека. } \\
\text { буквальный перевод: Кочан капусты / Деревянная башка / Репа - о глупом или } \\
\text { упрямом человеке, не желающим слушать ничьи советы (прим. - Теstа di raра } \\
\text { - Репа - наиболее уничижительное сравнение). } \\
\text { - Теsta di turсо } \\
\text { буквальный перевод: «Голова турка», т.е. несчастный человек, который всегда } \\
\text { виноват во всём, «стрелочник»; предмет насмешек. } \\
\text { Пример: Ё luі сһе fа da tеstа di turсо! Аналогия в русском языке - «На бедного } \\
\text { Макара все шишки валятся». } \\
\text { Историческая справка: В период средневековья рыцари для военной подго- } \\
\text { товки упражнялись на вращающихся манекенах, голова которых напоминала } \\
\text { обобщенный образ врага - турка в тюрбане. Также долгое время во всех бала- } \\
\text { ганах Европы в качестве мишени для стрельбы использовали образ «зловещего } \\
\text { турка». } \\
\text { Следует отметить, что до наших дней в Италии сохранилось восклицание, сим- } \\
\text { волизирующее некий страх или ужас: «Матта li turсhi!». }\end{array}$ & $\begin{array}{l}\text { Co словом tête (голова): } \\
\text { tête-à- tête - с глазу на глаз } \\
\text { un coup de tête - безрассудный, необдуманный поступок } \\
\text { la tête de Turc - объект насмешек } \\
\text { c'est sans queue ni tête - тут нет ни начала, ни конца, полная мешанина } \\
\text { tenir tête à qch - противостоять, давать отпор чему-либо } \\
\text { Co словом cœur (сердце): } \\
\text { le coup de cœur - особая расположенность, увлечение } \\
\text { par cœur - наизусть } \\
\text { dîner par cœur - обойтись без обеда } \\
\text { en plein cœur - в самой гуще, в самый разгар } \\
\text { haut les cœurs! - выше голову, не вешать нос! } \\
\text { à cœur joie - вволю, досыта } \\
\text { à votre bon cœur ! - подайте милостыню! } \\
\text { loin des yeux, loin du сœur - с глаз долой, из сердца вон } \\
\text { cœur et chaumière - с милым рай и в шалаше }\end{array}$ \\
\hline
\end{tabular}


ление диминутивов в переводах сказки С. Лагерлёф «Чудесное путешествие Нильса» на романские языки представлено в следующей таблице:

Лексические единицы Синтетические Аналитические Итого французский 38000031127158 итальянский 3600009643139

В переводах процент синтетических диминутивов по отношению ко всем диминутивным образованиям выражается в следующих цифрах (в скобках их процент в оригинальных произведениях): 80 (85) в итальянском, 77 (86) в португальском, 71 (89) в испанском, 55 (98) в румынском, 19 (7) во французском (Hasselrot 1957: 280281). Таким образом, эти подсчёты ещё раз подтверждают наибольшую степень аналитизма суффиксального словообразования французского языка по сравнению с другими романскими языками.

\section{Выводы}

Согласно лингвистическим исследованиям, французский язык заимствовал около 2000 слов из итальянского языка. Среди языков Европы итальянский входит в число тех, откуда во французский язык перешло наибольшее количество слов, а поскольку оба языка произошли от латыни, фонетическое усвоение слов происходит так легко и естественно, что они практически не выделяются в речи и больше не определяются как итальянизмы.

Устойчивые выражения в итальянском и французском языках также имеют много общего. В таблице противопоставляются устойчивые выражения на французском и итальянском с частями тела.

Как видно из приведенных примеров устойчивые выражения с названиями частей тела широко представлены в обоих языках, имеют широкий узус употребления.

\section{ЛИТЕРАТУРА}

1. Лопатникова H.H. Lexicologie du française moderne: для институтов и факультетов иностранных языков / Н.Н. Лопатникова, Н.А. Мовшович. - 2-е изд. М.: Высшая школа, 1971. - 232 с.

2. Горская С.А. Практикум по современному русскому языку: Лексика. Фразеология. Лексикография / С.А. Горская [Электронный ресурс]. - Режим доступа: www.ebooks.grsu.by/prakt_sov_rus

3. Jean Pruvost La Langue Française: Une Longue histoire Riche D’Emprunts / Université de Cergy-Pontoise [Электронный ресурс]. - Режим доступа.

4. Виноградов В.С. Грамматика испанского языка , 8-е изд. М.: КДУ, $2008-432$ с.

5. Гак В.Г. Сопоставительная лексикология (на материале французского и русского языков) М. 1977, 2-е изд. КД Либроком УРСС, 2010

6. Диасиамидзе В.Г. Словообразовательные модели имён существительных во французском и испанском языках, М.: изд. иностранной литературы , $1950-164$ c.

7. Катагощина Н.А. Как образуются слова во французском языке , М.: Просвещение, 1980. КД Либроком УРСС, 2005

8. Корж В.И. Quelques observations sur la féminisation des métiers, grades, titres et fonctions en français moderne// Романские языки в эпоху глобализации. Лингвистический и социолингвистический аспекты: Материалы международной конференции, М., 2010. С. 248-259

9. Овчинникова Г.В. Сопоставительный анализ признаковых слов во французском, итальянском и русском языках. Тула: Тульский государственный педагогический университет им. Л.Н. Толстого, $1999-250$ с.

10. Скуратов И.В. Типологические характеристики неологизмов в современном разговорном и деловом французском языке: лингвистические и социолингвистические аспекты,М. $2006-273$ с.

11. Степанов Ю.С. Структура французского языка: морфология, словообразование, основы синтаксиса в норме французской речи, М., 1965

12. Цыбова И.А. Perspective de l'étude confrontative de la formation de mots en français et en italien// Департамент образования г. Москвы. Московкий гуманитарный педагогический институт. Учёные записки, т. 6, М. 2008, с. 497-507

13. Цыбова И.А. 0 современных исследованиях словообразования во французском языке// Научные доклады высшей школы. Филологические науки. 1987, № 1 - с. $47-53$

14. Цыбова И.А. Словообразование в современном французском языке, М.: Высшая школа, 2008 а - 128 с.

15. Tsybova I.A. Lexicologie française / Цыбова И.А. Французская лексикология , М. : КД Либроком УРСС, 2010 - 223 с.

( К Кривошеева Елена Николаевна (krivosheeva.elena.1969@mail.ru), Лихачева Ирина Федоровна (irina_liha@mail.ru).

Журнал «Современная наука: актуальные проблемы теории и практики» 